\title{
THE EFFECT OF WORK STRESS, WORK CONFLICT, AND THE WORK ENVIRONMENT ON WORK SPIRIT IN EMPLOYEES PRATAMA TAX SERVICE OFFICE (KPP) BINJAI
}

\author{
Rosmani Sinaga \\ Sekolah Tinggi Ilmu Kesehatan Mitra Husada Medan \\ Email: rosmanisinaga11@gmail.com \\ Sutaryat Trisnamansyah \\ Universitas Islam Nusantara (UNINUS) Bandung \\ Email: yatsutaryat@ymail.com \\ Husen Saeful Insan \\ Universitas Islam Nusantara (UNINUS) Bandung \\ Email: huseninsan@gmail.com \\ Waska Warta \\ Universitas Islam Nusantara (UNINUS) Bandung \\ Email: waskawarta@gmail.com
}

\begin{abstract}
Tax Service Office (KPP) of the Directorate General of Taxes (DGT) work unit that provides taxation services to the public, whether registered as Taxpayers (WP) or not, within the scope of the Directorate General of Taxes working area. The problem of this research is whether work stress, work conflict, and work environment affect the morale of employees of the Pratama Binjai Tax Office (KPP). The data collection technique in this study was carried out with a questionnaire by distributing a list of questions to 53 respondents, from the results of the Fcount value of 4489.184 with a significant level of 0.00 . Because Fcount $4489.184>$ Ftable 2.79 and the significant probability is much smaller than 0.05 , namely $0.00<0.05$, the regression model can be said that work stress, work conflict, and work environment simultaneously have a positive and significant effect on morale. work. Partial test (t-test) shows that: for the variable work stress, the value of tcount is $4.465<$ ttable 1.676 with a significant value of $0.029>0.05$, meaning that partially, the variable of work stress has a positive and significant effect on morale. Work conflict variable value tcount $18.576>$ ttable 1.676 with a significant $0.000<0.050$, meaning that partially the work conflict variable has a positive and significant effect on morale. Work Environment Variable tcount 19.648> ttable 1.676 with a significant $0.001<0.050$, meaning that partially the Work Environment variable has a positive and significant effect on morale. The determination test is the adjusted $\mathrm{R}$ square of 0.996 , this means that $99.6 \%$ of the variation in morale can be explained by the independent variables of work stress, work conflict, and work environment while the rest $(100 \%-99.6 \%=0.4 \%)$ can be explained by other independent variables which not included in this study.
\end{abstract}

Keywords: Job Stress, Work Conflict, Work Environment and Work Spirit 


\section{A. INTRODUCTION}

Most people experience stress when they get a situation that is not according to their abilities. The large number of work tasks that are not balanced with skills and poor physical conditions are one of the factors that cause job stress. In general, work stress is more detrimental to employees and the company. Stress that increases until work reaches its optimal point is good stress that pleases euastress. Near, before reaching its optimal point, the event or situation is experienced as a stimulating challenge. Past the optimal point of stress becomes distress, the event or situation is experienced as an alarming threat.

Job stress arises due to the demands of a lot of work, personal problems of employees and so on. The lack of focus on work makes the job not completed properly or on time, which has an impact on their performance as an employee in an organization. Stress in a positive concept means that if stress can be managed properly, it will foster enthusiasm and motivation at work. On the other hand, stress that cannot be managed properly will cause many problems both physically and non-physically. Physically, it will cause health problems such as headaches, insomnia, heart attacks, high blood pressure, and strokes. Meanwhile, stress that causes problems non-physically will affect one's thinking or mental processes.

Work conflict is a mismatch between two or more members or groups of a company due to the fact that they have different status, goals, values or perceptions. In addition, conflict is defined as differences, contradictions, and disputes, conflicts that are contrary to group goals are called dysfunctional conflicts. There are work conflicts that are dysfunctional, namely, dominating discussions, displeasing to work in groups, personality clashes, disputes between individuals and tensions.

The work environment is an environment where employees do their daily work. A conducive work environment provides a sense of security and allows employees to work optimally. The work environment can affect employee emotions. If an employee likes the work environment where he / she works, then the employee will feel at home in the workplace to carry out activities so that work time is used effectively and optimists that the employee's work performance is also high.

Morale shows the extent to which employees are passionate about carrying out their duties and responsibilities in the company. Employee morale can be seen from attendance, discipline, timeliness of completing work and responsibilities. The role of human resources in the company is very important in order to create the continuity of company performance. The morale factor must be known by company leaders or managers because it is important for the success of a business. It is said that it is important for the success of a business because morale can affect employee productivity and work potential. Optimal work spirit must be supported by employee motivation to work optimally

Stress factors, conflict and a good work environment are factors that must be considered to encourage employee morale in a company.

The sources of Indonesian State revenue from various sectors where all the proceeds of this revenue will be used to finance development and improve the welfare of all Indonesian 
people. One of the most potential sources of state revenue is tax revenue. Taxes are a source of state revenue which has a very big influence on the wheels of State government. In order to increase more optimal tax revenue, the government is highly expected to participate in fulfilling its tax obligations based on taxation provisions. In order to improve services for taxpayers, the government opens access to tax services in the Binjai area

Based on the results of the author's interview at the Binjai Pratama Tax Office (KPP), it was found that several phenomena have resulted in decreased employee morale, among others, which can cause work stress, among others: Factors that can cause work stress on employees include, work, social support, experience, personality type, suitability of salaries, and workload. In fact, there has been a conflict between employees, many things have caused this conflict to occur. Like misunderstandings, employee personal problems that are brought to work can also cause disputes, the work pressure of each employee who is required to continue to achieve their targets is often the reason for conflicts between fellow employees.

The work environment of employees at the Pratama Binjai Tax Office (KPP) is less comfortable, the layout / layout does not provide sufficient space for the job to be carried out. The layout / layout has never changed, causing boredom and decreased morale of employees in carrying out their duties.

Based on the description above, the authors are interested in conducting research with the title: "The Effect of Work Stress, Work Conflict, and Work Environment on Morale of Employees of the Tax Office (KPP) Pratama Binjai".

\section{B. METHOD}

The method used in this research is descriptive research with a quantitative approach that aims to reveal what it is. According to Arikunto, he revealed that descriptive research was not intended to test certain hypotheses, but only described what it is about a variable (Arikunto, 2005. p. 26). According to Arikunto, with quantitative research, many are required to use numbers, starting from data collection, interpretation of the data, and the appearance of the results. So it can be concluded that quantitative descriptive research in this research is to see, review and describe in numbers about the object under study as it is and draw conclusions about it according to the phenomena that appear at the time the research was conducted. (Arikunto, 2006. p. 12).

According to Rusiadi, Subiantoro and Hidayat. Associative / quantitative research is a study that aims to determine the degree of relationship and the pattern / form of influence between two or more variables, where this research will build a theory that functions to explain, predict and control a symptom "(Rusiadi dkk., 2016. p. 12).

Research Location at the Tax Office (KPP) Pratama Binjai. Jalan Jambi No.1, Rambung Barat. South Binjai. Binjai City.

\section{RESULTS AND DISCUSSION}




\section{Spirit at Work \\ Definition of Morale}

Basically, morale is related to the needs of employees, if employee needs are met, employee morale will tend to increase, it is necessary to fulfill employee needs in order to increase employee morale. The importance of morale can be seen as a fundamental part of management activities so that something can be aimed at directing human potential and power by generating, animating, growing a high level of desire and togetherness in carrying out individual and organizational tasks. To discuss the morale of work, there are many definitions expressed by experts about morale, including: Morale as any willingness to feel that allows someone to work to produce more and better work (Hariyanti, 2015. p.155).

\section{Factors Affecting Morale}

According to Namawi the factors that affect the level of morale:

1) A person's work conflict with the work being performed.

2) Job Stress

3) Social status of work.

4) Work environment and work relationships.

5) Purpose of work (Namawi, 2013. p.52).

Employee morale problems in companies are often found, therefore companies must be able to increase employee morale so that they can do their job well and quickly.

Morale Indicator

According to Hasibuan, the indications of decreasing employee morale include:

1) Low work productivity

2) Increased and high level of absenteeism

3) Labor turn over or high employee turnover

4) Increased damage rate

5) Restlessness everywhere

6) Demands that often occur

7) Strike (Hasibuan, 2013. p.431)

\section{Job Stress \\ Definition of Work Stress}

Stress is the inability to overcome the threats faced by mental, physical, emotional and spiritual humans which at one time can affect human physical health. Stress is our perception of a situation or condition in our own environment. Another definition states stress is a condition of tension that affects one's emotions, thought processes, and conditions. If an employee experiences too much stress, it interferes with that person's ability to deal with the environment and work (Handoko, 2012. p.193).

Job stress is a condition of tension that creates a physical and psychological imbalance, which affects emotions, thought processes, and the condition of an employee. Too much stress can threaten a person's ability to deal with the environment. As a result, employees develop various kinds of stress symptoms that can interfere with employee performance. Employees who experience stress can become nervous and experience chronic anxiety. 
Employees often become irritable and aggressive, unable to relax, or display uncooperative attitudes.

Based on the above understanding, it can be concluded that work stress is a condition of tension that causes an imbalance in the physical and psychological conditions of employees who come from individuals and organizations so that it affects the physical, psychological, and employee behavior.

Factors Causing Job Stress

Another opinion from Hasibuan states the factors that cause work stress:

1) Difficult and excessive workload

2) Pressure and attitude from leadership that is not fair and reasonable

3) Inadequate work time and equipment

4) Conflict between individuals and leaders or with work groups

5) Remuneration is too low

6) Family problems such as children, wives, in-laws and others (Hasibuan, 2013. p.201).

Job Stress Indicator

Robbins states, the work stress model which is an indicator of work stress is:

1) Workload, measured from the respondent's perception of the perceived workload as excessive.

2) The attitude of the leader, measured by the respondent's perception of the leader's unfair attitude in giving tasks.

3) Working time, measured from the respondent's perception of the perceived excessive working time.

4) Conflict, measured from the respondent's perception of the conflict between employees and leaders.

5) Communication, measured from the respondent's perception of poor communication between employees.

6) Work authority, measured from the respondent's perception of work authority relating to responsibility (Robbins, 2010. p.204).

\section{Work Conflict}

\section{Definition of Work Conflict}

In human life, including in the world of work, the name conflict is inseparable. Conflicts usually arise in work as a result of problems with communication, personal relationships or organizational structure. The mismatch between two more members or organizational groups arises from the fact that they have different status, goals, values and perceptions.

According to Stoner work conflict is a difference of opinion between two or more members of an organization or group, because they have to share scarce resources or work activities or have different status, goals, assessments, or views (Stoner, 2015. p.85).

Meanwhile, according to Tommy work conflict is a form of conflict that occurs in organizations caused by differences in goals, communication errors, dependence on work activities, differences in judgment and effective errors (Tommy, 2010. p.85). According to Mangkunegara a work conflict is a conflict that occurs between what a person hopes for 
himself, another person, an organization and the reality of what is expected (Mangkunegara, 2013. p.92).

Thus it can be concluded that work conflict is the occurrence of a conflict between individuals and other individuals or the existence of a mismatch of conditions experienced by employees because of communication barriers, differences in goals, communication errors, differences in judgment about work and dependence on work activities.

Forms of Conflict in Organizations

According to Mangkunegara there are four forms of organizational conflict, namely:

1) Hierarchical Conflict

2) Functional Conflict

3) Staff Conflict with the Unit Head

4) Formal-Informal Conflict (Mangkunegara, 2013. p. 155)

Causes of Conflict

According to Anorogo and Widiyanti the causes of conflict are three, namely:

1) Dissent

2) Misunderstood

3) One or both parties feel aggrieved (Anorogo \& Widiyanti, 2013. p. 160)

Effects of Work Conflict

Tommy (states that the positive consequences of work conflicts are as follows:

1) Creates the ability to self-erode

2) Develop better alternatives

3) Better approach (Tommy, 2010. p.96)

Work Conflict Indicators

The work conflict indicator Luthans consists of five indicators, including:

1) Functional conflict:

a. Competing for achievements.

b. Positive movement towards goals.

c. Stimulate creativity and innovation.

d. Encouragement to make changes.

2) Dysfunctional Conflict:

a) Dominate the discussion.

b) Not happy working in groups.

c) Personality clashes.

d) Disputes between individuals (Luthans, 2015. p. 137)

\section{Work environment \\ Definition of Work Environment}

The work environment of a company needs to be considered, this is because the work environment has a direct influence on employees. A conducive work environment can improve employee performance and vice versa, an inadequate work environment can reduce employee performance. The condition of the work environment is said to be good if humans can carry out activities in an optimal, healthy, safe and comfortable manner. 
Herman Sofyandi defines "the work environment as a series of factors that affect the performance of human resource management functions / activities consisting of internal factors that come from within the organization" (Sofyandi, 2018. p. 38).

According to Schultz \& Schultz the work environment is defined as a condition related to the characteristics of the workplace towards employee behavior and attitudes where it is related to the occurrence of psychological changes due to things experienced in their work or in certain circumstances. which organizations should continue to pay attention to which includes work boredom, monotonous work and burnout (Schultz \& Schultz, 2016. 149)

The work environment consists of physical and non-physical environments that are attached to employees so that they cannot be separated to get good employee performance

Factors affecting the Work Environment

Work environment factors described by Sedarmayanti that can affect the formation of a work environment are related to the ability of employees, including:
1) Color
2) Cleanliness of the work environment
3) Lighting
4) Air exchange
5) Guarantee of security
6) Noise
7) Layout (Sedarmayanti, 2010. p.73)

Work Environment Indicator

Work environment indicators by Nitisemito are:

1) Work atmosphere

2) Relationships with colleagues.

3) Availability of work facilities (Nitisemito, 2012. p.159)

\section{Validity Test and Reliability Test Validity test}

The validity test to determine the appropriateness of each questionnaire that has been given to the respondent requires a validity test to measure whether a questionnaire is valid or not.

If each question has a value of $>0.30$ then the question is declared valid (valid). Based on the Table of Validity Test Results, the product correlation coefficient value of the product moment is the score of each question item with the total of all question items in the corrected item total correlation column.

From the data, all coefficient values exceeding 0.30 , it is stated that all questions and the scores obtained are valid (valid).

Reliability Test 
The reliability test (reliability) is to determine the stability and consistency of the respondent in answering the items related to the constructs of questions arranged in a questionnaire form. The reliability of a variable construct is said to be good if it has a Cronbach's Alpha value $>0.60$.

Based on the Table of Reliability Test Results, there is a cronbach's alpha of $0.982>0.60$ so it can be concluded that the construct of questions that have been presented to the respondent consists of 31 items, both in work stress (X1), work conflict (X2), and work environment variables. $(\mathrm{X} 3)$, while for variable $\mathrm{Y}$, namely: morale is reliable or reliable.

\section{Data analysis technique Classic assumption test Normality test}

The normality test aims to test whether it is feasible to use multiple regression, as it is known that the partial effect test assumes that the residural value follows a normal distribution..

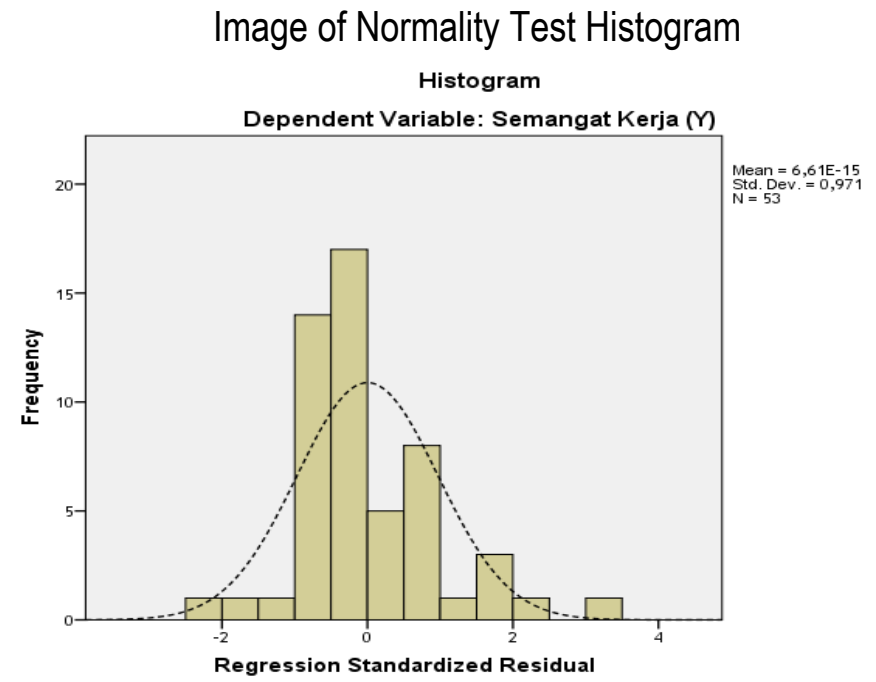

Based on the image of the Normality Test Histogram, the results of the data normality test show that the data has been normally distributed, where the histogram above has a curved line to form like a bell..

Figure PP Plot Normality Test 


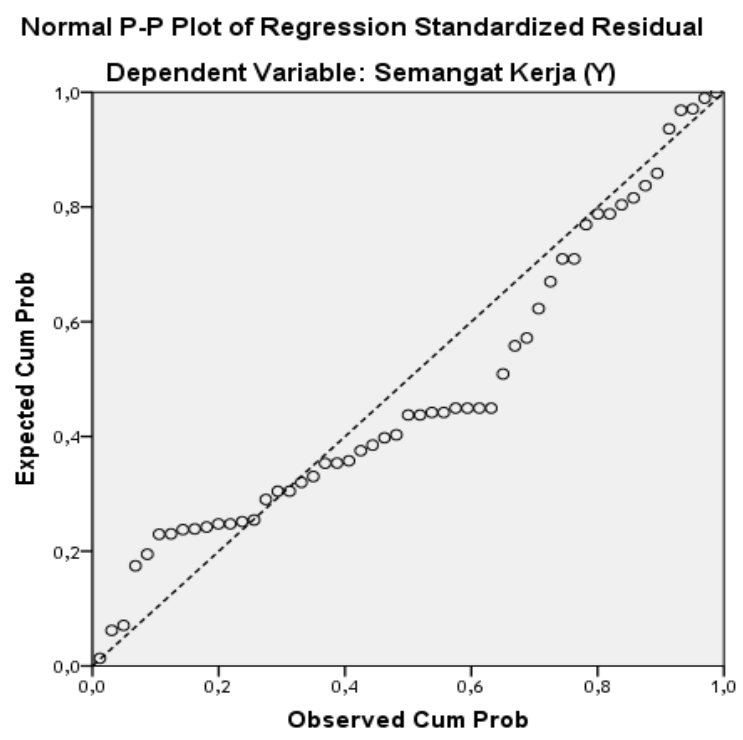

Based on the PP Plot Normality Test Figure, it can be seen above the distribution of points on work stress (X1), work conflict (X2), and work environment (X3). that the data presented can be said to be normal.

\section{Multicollinearity Test}

The cut off value used to indicate the presence or absence of multicollinearity is:

VIF $<10=$ multicollinearity

Tolerance $<10=$ no multicollinearity

Multicollinearity Test Results Table

Coefficientsa

\begin{tabular}{|l|l|c|c|}
\hline \multicolumn{2}{|l|}{ Model } & \multicolumn{2}{c|}{ Collinearity Statistics } \\
\cline { 2 - 4 } 1 & (Constant) & & Volerance \\
\cline { 2 - 4 } & Job Stress (X1) &, 182 & \\
\cline { 2 - 4 } & Work Conflict (X2) &, 182 & 5,482 \\
\cline { 2 - 4 } & Work environment (X3) &, 182 & 5,482 \\
\hline
\end{tabular}

a. Dependent Variable: Spirit at work $(\mathrm{Y})$

Based on the Table of Multicollinearity Test Results, the VIF number of variable work stress (X1), work conflict (X2), and work environment (X3) is 5.482 which means less than 10 and the tolerance value for work stress (X1), work conflict (X2), and work environment (X3) is 0.182 smaller than 10 , it can be concluded that the regression model is free of multicollinearity interference or does not occur multicol.

\section{Heteroscedacity test}

If $t$ count> $t$ table, it means heteroscedasticity or vice versa homoscedasticity or it can be seen from the significant probability> 0.05 . 
Image of Heteroscedasticity Test Results

Scatterplot

Dependent Variable: Semangat Kerja $(\mathrm{M})$

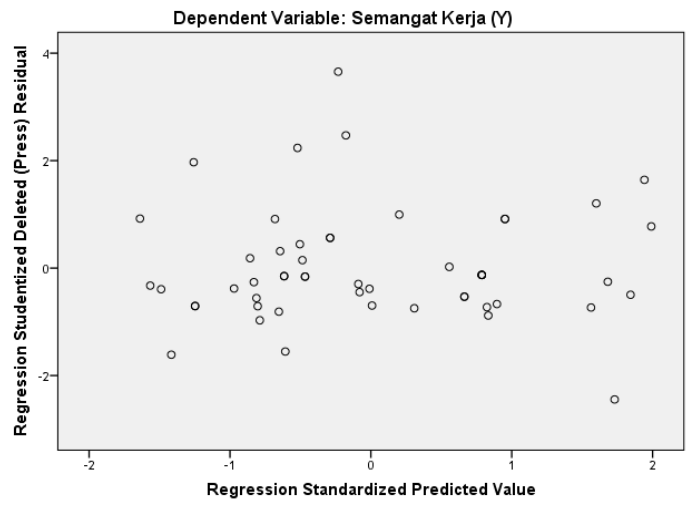

Based on the Figure of Heteroscedasticity Test Results the dots are random or do not form a certain clear pattern. This shows that there is no heteroscedasticity in the regression model, so this regression model is suitable for this study

\section{Multiple Linear Regression Equation}

Regression analysis is a data analysis technique in statistics that is often used to examine the relationship between several variables and predict a variable..

Multiple Linear Regression Equation Table

\begin{tabular}{|c|c|c|c|c|}
\hline \multicolumn{5}{|c|}{ Coefficients ${ }^{a}$} \\
\hline \multirow{2}{*}{\multicolumn{2}{|c|}{ Model }} & \multicolumn{2}{|c|}{ Unstandardized Coefficients } & \multirow{2}{*}{$\begin{array}{r}\text { Standardized Coefficients } \\
\text { Beta }\end{array}$} \\
\hline & & $\mathrm{B}$ & Std. Error & \\
\hline \multirow[t]{4}{*}{1} & (Constant) & 1,495 & ,374 & \\
\hline & Job Stress (X1) & 123 & .028 & .090 \\
\hline & Work Conflict (X2) &, 539 &, 029 & 431 \\
\hline & Work environment (X3) & 1,194 & 061 & 665 \\
\hline
\end{tabular}

a. Dependent Variable: Spirit at work $(\mathrm{Y})$

Based on the Coefficients Table, the regression equation is $Y=1.495+0.123 \mathrm{X} 1+0.539$ $\mathrm{X} 2 .+1.194 \mathrm{X} 3 \mathrm{~A}$ constant of 1.495 states that if there is no independent variable (value 0 ) then the dependent variable remains diversification of work stress $(X 1)$ of 0.123 , work conflict (X2) is 0.539 and the work environment (X3) is 1.194 it can be concluded that hypothesis 1 is accepted

\section{Hypothesis test}

\section{Simultaneous Influence Test (simultant)}

The purpose of the $F$ test is to show whether all the independent variables included in the model have joint influence (simultaneously) the independent variable $(X)$ on the dependent variable $(\mathrm{Y})$.

Based on the F-Test Result Table, the F test results in an F-count value of 4489.184 with a significant level of 0.00 . Because Fcount 4489.184> Ftable 2.79 and the significant probability is much smaller than 0.05 , namely $0.00<0.05$, the regression model can be said 
that work stress, work conflict, and work environment simultaneously have a positive and significant effect on morale. work.

Partial Effect Test

The test results of the influence of work stress, work conflict, and work environment variables on the morale of the employees of the Pratama Binjai Tax Office (KPP) are in the following table:

The t-test shows how much influence the independent variables individually have on the dependent variable.

The test uses the following steps:

1) Test the effect of work stress on morale Based on the t-test results table for work stress, the value of tcount is $4.465<\mathrm{ttable}$ 1.676 with a significant $0.029>0.05$, meaning that partially the work stress variable has a positive and significant effect on morale.

2) Test the effect of work conflict on morale

Based on the t-test results table work conflict t-value 18.576>t table 1.676 with a significant $0.000<0.050$, meaning that partially work conflict variables have a positive and significant effect on morale.

3) Test the influence of the Work Environment on morale

Based on the t-test result table for the work environment, the value of $t$ count $19.648>t$ table 1.676 with a significant $0.001<0.050$, meaning that partially the work environment variable has a positive and significant effect on morale.

\section{Coefficient of Determination}

The results of the determination test (R2) can be seen from the value of the coefficient of determination, the amount of the adjusted $\mathrm{R}$ square is 0.996 , this means that $99.6 \%$ of the variation in morale can be explained by the independent variables of work stress, work conflict, and work environment while the rest $(100 \%-99.6 \%=0.4 \%)$ can be explained by other independent variables that were not included in this study.

\section{CONCLUSSIONS}

Based on the analysis and discussion carried out on the research data obtained, the following conclusions are drawn:

1. 1. Based on the results of the research that has been conducted, it shows that the $F$ test results in an $F$ count of 4489.184 with a significant level of 0.00 . Because Fcount 4489.184> Ftable 2.79 and the significant probability is much smaller than 0.05 , namely $0.00<0.05$, the regression model can be said that work stress, work conflict, and work environment simultaneously have a positive and significant effect on morale. work.

2. 2. Based on the results of the research that has been done, it shows the variable work stress t-value of $4.465<t$ table 1.676 with a significant $0.029>0.05$, meaning that partially work stress variables have a positive and significant effect on morale.

3. 3. Based on the results of the research that has been done, it shows the work conflict variable value tcount $18.576>t$ table 1.676 with a significant $0.000<0.050$, 
meaning that partially the work conflict variable has a positive and significant effect on morale.

4. 4. Based on the results of the research that has been conducted, it shows the Work Environment variable tcount 19.648> ttable 1.676 with a significant 0.001 $<0.050$, meaning that partially the Work Environment variable has a positive and significant effect on work morale

5. 5. Based on the results of research that has been done, it shows the amount of an adjusted $\mathrm{R}$ square of 0.996 , this means that $99.6 \%$ of the variation in morale can be explained by the independent variables of work stress, work conflict, and work environment while the rest $(100 \%-99.6 \%=0.4 \%)$ can be explained by other independent variables that were not included in this study.

Based on the above conclusions, there are suggestions regarding work stress, work conflicts, and the work environment. These suggestions are:

1. Suggestions for work stress, it is suggested that the leader can understand the abilities and experience as well as the expertise of employees in giving jobs to employees so that employees are truly ready to face work-related problems.

2. For work conflicts, it is advisable to the leadership to be able to socialize the vision and mission of the organization, so that each employee has the same vision and mission in carrying out the work.

3. The work environment at the Binjai Pratama Tax Office (KPP) is recommended so that the work atmosphere, motivation or encouragement given to complete work on time can be the full attention of the service employee leadership, and workplace environment indicators to strive for noise from the workshop so as not to affect communication between employees.

4. From work spirit, employees must be even more active in working in order to get maximum results. In this case also requires awareness from the employees themselves, such as willingness to work hard, time discipline and discipline at work. If employees do not have a sense of awareness of this, there will be an adverse impact on the organization.

\section{References}

Anorogo, \& Widiyanti. (2013). Manajemen Produksi Pengendalian Produksi. BPFE.

Arikunto, S. (2005). Prosedur Penelitian Suatu Pendekatan Praktek. PT Rineka Cipta.

Arikunto, S. (2006). Metode Penelitian Kualitatif. Bumi Aksara.

Handoko. (2012). Perilaku dan Budaya Organisasi. PT Refika Aditama.

Hariyanti. (2015). Manajemen Sumber Daya Manusia Untuk Perusahaan. PT Raja Grafindo Persada.

Hasibuan, SP. M. (2013). Manajemen Sumber Daya Manusia. PT. Bumi Aksara.

Luthans. (2015). Organisasi dan Motivasi: Pasar Peningkatan Produktivitas. Bumi Angkasa.

Mangkunegara, A. P. (2013). Manajemen Sumber Daya Manusia Perusahaan. Remaja Rosda Karya. 
Namawi. (2013). Organisasi dan Motivasi: Pasar Peningkatan Produktivitas. Bumi Angkasa.

Nitisemito, A. S. (2012). Manajemen Sumber Daya Manusia. Graha IImu.

Robbins. (2010). Manajemen Sumber Daya Manusia. PT Buku Seru. http://repository.upi.edu/17628/4/S_MBS_1001311_Bibliography

Rusiadi, Subiantoro, Nur, \& Muhammad. (2016). Metode Penelitian: Manajemen, Akuntansi dan Ekonomi Pembangunan. Konsep, Kasus dan Aplikasi SPSS, Eviews, Amos, Lisrel. USU Press.

Schultz, D., \& Schultz, E. S. (2016). Psychology and work today. Pearson.

Sedarmayanti. (2010). Sumber Daya Manusia dan Produktivitas Kerja. Mandar Maju.

Sofyandi, H. (2018). Human Resource Management: Manajemen Sumber Daya Manusia (D. Angelia, Penerj.). Salemba Empat.

Stoner. (2015). Manajemen. PT. Prenhallindo.

Tommy. (2010). Manajemen Strategik Organisasi NonProfit Bidang Pemerintahan. Gajah Mada University Perss. 